\title{
Intestinal parasites in public transport buses from the city of Diamantina, Minas Gerais, Brazil
}

This article was published in the following Dove Press journal:

Research and Reports in Tropical Medicine

I June 2017

Number of times this article has been viewed

\author{
Sabrina S Andrade' \\ Layane M Teodoro' \\ Daniel JS Viana' \\ Egleise M Canuto-Sales ${ }^{2}$ \\ Gustavo H \\ Bahia-de-Oliveira ${ }^{2}$ \\ Suedali Villas Bôas ${ }^{3}$ \\ Ricardo A Barata' \\ 'Department of Biological Sciences, \\ ${ }^{2}$ Department of Pharmacy, \\ ${ }^{3}$ Department of Basic Sciences, \\ Universidade Federal dos Vales do \\ Jequitinhonha e Mucuri, Diamantina, \\ Minas Gerais, Brazil
}

Background: Intestinal parasites' eggs, larvae, or cysts can be carried in public transport buses, and contribute to the increased incidence of diseases. This study aimed to detect biological forms of intestinal parasites in samples from public buses in the town of Diamantina, Minas Gerais, in order to know the local situation and propose interventions to improve public health. Materials and methods: In November 2014, six samples were obtained in buses of the two stations by using Graham method, in duplicate, by affixing a $6 \times 5 \mathrm{~cm}$ clear tape, six times on each collection site of the bus, in an area of $\sim 30 \mathrm{~cm}^{2}$. Then, each tape was positioned longitudinally on a slide microscope, and the identification of the biological forms of the parasites was performed with the aid of a $40 \times$ objective optical microscope.

Results: A total of 216 slides were analyzed, of which 86 (39.8\%) were positive for at least one intestinal parasite. Cysts of Entamoeba coli were the most frequently found in this study (52.1\%), followed by Endolimax nana cysts (30.7\%), Iodamoeba butschlii (6.5\%), helminth larvae (4.7\%), Giardia lamblia cysts (3.6\%), Hymenolepis nana eggs (1.2\%), Enterobius vermicularis eggs $(0.6 \%)$, and Entamoeba histolytica cysts $(0.6 \%)$. Top right handrails and right stanchions had the highest occurrence of biological forms, with $18.3 \%$ and $14.8 \%$, respectively. Conclusion: The results indicated the need for better cleaning of the buses and better personal hygiene by users, since pathogenic and non-pathogenic intestinal parasites were found, suggesting fecal contamination of these sites, representing a risk to public health.

Keywords: intestinal parasites, enteric parasite infection, public transport, Diamantina

\section{Introduction}

Intestinal parasitoses or enteroparasitoses is a group of diseases caused by helminths or protozoans affecting $\sim 2$ billion people worldwide, reaching high prevalence rates in some regions. ${ }^{1}$ In Brazil, the occurrence of these diseases may vary according to sanitation conditions, socioeconomic level, and population health habits, becoming a major public health problem in the country, mainly in large cities' peripheries. $^{2}$

Intestinal parasites have a direct physiological effect on the health and nutritional balance of infected individuals. ${ }^{3}$ The vulnerable populations, living in regions with inadequate sanitation conditions, in need of effective health education are the most affected by these pathologies. ${ }^{4}$ Diarrhea, for example, is one of the conditions in children contributing to malnutrition, affecting both growth and cognitive development of infected individuals, among other complications. ${ }^{5-7}$

The spread of infectious forms of intestinal parasites is a determining factor for the increased incidence of intestinal parasites in Brazil. The eggs, larvae, or cysts
Correspondence: Ricardo A Barata Departamento de Ciências Biológicas, Universidade Federal dos Vales do Rodovia MGT-367, Km 583, 5000, Alto da Jacuba, 39100-000, Diamantina, Minas Gerais, Brazil

Tel +55383532 I200

Email ricbarata@hotmail.com 
of parasites, can be spread in several ways: greens and vegetables sold in street fairs, ${ }^{8,9}$ money (paper bills), ${ }^{10-12}$ mechanical vectors, ${ }^{13,14}$ pacifiers, ${ }^{15}$ school toilets, ${ }^{16}$ health basic units, ${ }^{17}$ public transportation buses, ${ }^{18}$ among others.

Public transport buses can be an important source of transmission of infectious forms of parasites, since a large number of passengers are in constant contact with these internal parts of the vehicle. Thus, the aim of this study was to investigate biological form occurrences of intestinal parasites present in transport buses from the city of Diamantina, in order to assess the local current situation and propose interventions aiming to improve local public health.

\section{Materials and methods}

The town of Diamantina (Lat $18^{\circ} 14^{\prime} 58^{\prime \prime} \mathrm{S}$ and Long $43^{\circ} 36^{\prime} 01^{\prime \prime} \mathrm{W}$ ) (Figure 1) located in the Jequitinhonha River Valley has become historically famous for its mineral riches, such as gold and diamonds. Diamantina is currently one of the most visited cultural and tourist spots in Brazil. It has a population of 45,880 inhabitants, ${ }^{19}$ built on large quartzite formations composing the Espinhaço Mountain Range.

The Universidade Federal dos Vales dos Jequitinhonha e Mucuri, $5 \mathrm{~km}$ from the center of Diamantina, has two bus lines which transport students, staff, and others who use the services of the university. The buses serve $\sim 5,000$ users daily, comprising people from different social classes and hygiene habits.

In November 2014, six samples were collected using the Graham method, ${ }^{20}$ by affixing a $6 \times 5 \mathrm{~cm}$ clear tape, in duplicate, six times on each collection site in an area of $\sim 30 \mathrm{~cm}^{2}$. Biological material was collected in six buses of the Rio
Grande line and six buses of the Largo Dom João line. Nine areas in the buses were selected: top handrail (right and left), seat grab rails (right and left), door handholds, stanchions (right and left), and seats (right side and left). Samples were collected after a work day and before the bus cleaning was done. Thereafter, each tape was placed longitudinally on a microscope slide, and identification of the forms of parasites found (eggs, larvae, or cysts) was conducted with the aid of an optical microscope with a $40 \times$ objective. This methodology was similar as performed by Pereira et al. ${ }^{21}$

Absolute values were subjected to analysis of variance, and the means were compared by the Tukey's test, with a significance level of $5 \%(p \leq 0.05)$ by using SISVAR version 5.0 software. $^{22}$

\section{Results}

A total of 216 slides were analyzed, of which 86 (39.8\%) were positive for at least one intestinal parasite. A total of 169 biological forms of intestinal parasites were detected. Cysts of Entamoeba coli were the most frequently found in this study (52.1\%), followed by Endolimax nana cysts (30.7\%), Iodamoeba butschlii (6.5\%), helminth larvae (4.7\%), Giardia lamblia cysts (3.6\%), Hymenolepis nana eggs (1.2\%), Enterobius vermicularis eggs (0.6\%), and Entamoeba histolytica cysts $(0.6 \%)$. Top right handrails and right stanchions had the highest occurrence of biological forms, with $18.3 \%$ and $14.8 \%$, respectively (Table 1 ).

Table 2 shows the mean frequency of biological forms found per sample in the buses in the town of Diamantina. The results also showed that the Rio Grande and Largo Dom João had a very similar ratio of biological forms, but the mean

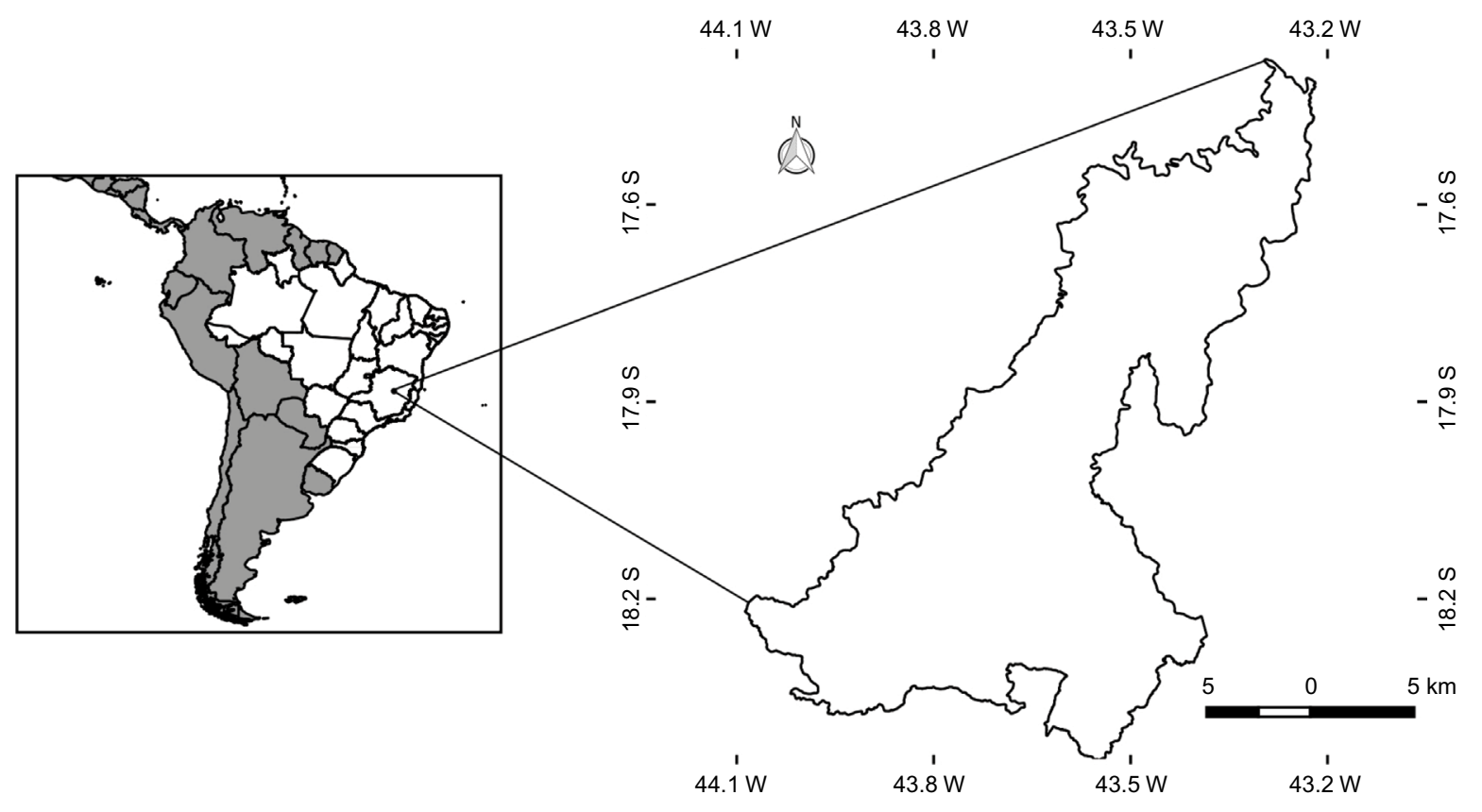

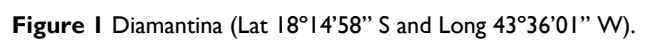


Table I Frequency of intestinal Parasites found in some areas inside public buses from the city of Diamantina, Minas Gerais (November 2014)

\begin{tabular}{|c|c|c|c|c|c|c|c|c|c|}
\hline \multirow[t]{2}{*}{ Sampling sites } & \multicolumn{8}{|c|}{ Intestinal parasites } & \multirow[t]{2}{*}{$\mathbf{N}(\%)$} \\
\hline & $\begin{array}{l}\text { Endolimax } \\
\text { nana }\end{array}$ & $\begin{array}{l}\text { Entamoeba } \\
\text { coli }\end{array}$ & $\begin{array}{l}\text { Entamoeba } \\
\text { histolytica }\end{array}$ & $\begin{array}{l}\text { Enterobius } \\
\text { vermicularis }\end{array}$ & $\begin{array}{l}\text { Giardia } \\
\text { lamblia }\end{array}$ & $\begin{array}{l}\text { Hymenolepis } \\
\text { nana }\end{array}$ & $\begin{array}{l}\text { lodamoeba } \\
\text { butschlii }\end{array}$ & $\begin{array}{l}\text { Helminth } \\
\text { larvae }\end{array}$ & \\
\hline Top handrails (right) & 5 & 12 & 0 & 0 & 2 & 0 & 10 & 2 & $31(18.3)$ \\
\hline Top handrails (left) & 7 & 14 & 0 & I & 0 & 1 & 0 & 0 & $23(13.6)$ \\
\hline Seat grab rails (right) & 7 & 7 & 0 & 0 & 1 & 0 & 0 & 1 & $16(9.5)$ \\
\hline Seat grab rails (left) & 2 & 5 & 1 & 0 & 1 & 0 & 0 & 1 & $10(5.9)$ \\
\hline Door grab rails & 6 & 10 & 0 & 0 & I & 0 & 0 & 0 & $17(10.0)$ \\
\hline Stanchions (right) & 9 & 13 & 0 & 0 & 1 & 0 & 0 & 2 & $25(14.8)$ \\
\hline Stanchions (left) & 10 & 8 & 0 & 0 & 0 & 0 & 0 & 0 & $18(10.7)$ \\
\hline Seat (right) & 4 & 5 & 0 & 0 & 0 & 0 & 0 & 1 & $10(5.9)$ \\
\hline Seat (left) & 2 & 14 & 0 & 0 & 0 & 1 & 1 & 1 & $19(11.3)$ \\
\hline Total & 52 (30.7\%) & 88 (52.1\%) & I $(0.6 \%)$ & I (0.6\%) & $6(3.6 \%)$ & $2(1.2 \%)$ & II (6.5\%) & 8 (4.7\%) & $169(100)$ \\
\hline
\end{tabular}

Table 2 Mean frequency of intestinal Parasites found per sample in public bus stations from the city of Diamantina, Minas Gerais (November 2014)

\begin{tabular}{|c|c|c|c|c|c|c|c|c|}
\hline \multirow[t]{2}{*}{ Stations } & \multicolumn{8}{|c|}{ Intestinal parasites } \\
\hline & $\begin{array}{l}\text { Endolimax } \\
\text { nana }\end{array}$ & $\begin{array}{l}\text { Entamoeba } \\
\text { coli }\end{array}$ & $\begin{array}{l}\text { Entamoeba } \\
\text { histolytica }\end{array}$ & $\begin{array}{l}\text { Enterobius } \\
\text { vermicularis }\end{array}$ & $\begin{array}{l}\text { Giardia } \\
\text { lamblia }\end{array}$ & $\begin{array}{l}\text { Hymenolepis } \\
\text { nana }\end{array}$ & $\begin{array}{l}\text { lodamoeba } \\
\text { butschlii }\end{array}$ & $\begin{array}{l}\text { Helminth } \\
\text { larvae }\end{array}$ \\
\hline Largo Dom João & 4.33 & 7.16 & 0.16 & 0.16 & 0.33 & 0.16 & 0 & 0.66 \\
\hline Rio Grande & 4.33 & 7.50 & 0 & 0 & 0.66 & 0.16 & 1.83 & 0.66 \\
\hline Coefficient of variation (\%) & 3.86 & 4.55 & 22.22 & 22.22 & 0.10 & 50.00 & 8.70 & 50.00 \\
\hline$p$-Value & 0.998 & 0.500 & 0.204 & 0.204 & $<0.01$ & 0.998 & 0.027 & 0.998 \\
\hline
\end{tabular}

frequency for G. lamblia and I. butschlii showed a statistically significant difference $(p \leq 0.05)$ between the stations (Table 2$)$.

\section{Discussion}

Parasites' eggs, larvae, and cysts may be spread in many ways. This work shows that public buses can be one of the sources of infection for passengers who use this means of transportation. Users with poor personal hygiene contaminate the internal parts of the vehicle with their dirty hands, enabling the transmission of pathogens and non-pathogens to other passengers.

The protozoans E. coli and E. nana showed high occurrence in the examined sites. Although they are not considered pathogenic, the presence of these organisms makes fecal contamination of human origin evident. The detection of $G$. lamblia and E. histolytica is worrying as these agents are considered pathogenic and cause symptoms such as diarrhea, abdominal pain, and cramps in the infected individuals. ${ }^{23}$

When analyzing surfaces at a school in the same locality, Pereira et $\mathrm{al}^{21}$ verified the marked presence of $E$. coli $(50 \%)$, as evidenced in the present study. Another fact that deserves attention is the similarity of the results when we analyze the percentage of I. butschlii, which is also practically the same in both studies. As it is a collective line of buses and school goers enjoy this type of transport, it may be that the same users are circulating in both environments.
$H$. nana eggs were observed in this work, but in a smaller number. This species of tapeworm has often been identified in samples of feces from hospitalized children and Indians, ${ }^{24,25}$ in Minas Gerais. H. nana detection also indicates users' poor hygiene, which may increase the risk of transmission in the endemic area. ${ }^{26}$

Borges et al, ${ }^{27}$ in a study conducted in Uberlândia, Minas Gerais, also found a positive result for E. vermicularis on the buses analyzed there. Enterobiasis, despite being more common in children, can also affect adults in their reproductive age and cause acute pain and discomfort. This study showed the presence of this helminth's eggs, which hampers good hygiene maintenance and eases transmission. ${ }^{28}$

The most contaminated parts of the buses in this study were the top handrails and stanchions, these data corroborate work from Murta and Massara, ${ }^{18}$ who found the highest infection rates in these bus points. These internal parts are in direct contact with people's hands that constantly hold them as safe support during transportation.

Finally, the results indicate the need for better cleaning of the buses and an implementation of educational campaigns to improve users' personal hygiene as pathogenic and nonpathogenic intestinal parasites were found, suggesting fecal contamination of these sites, representing risk to public health. 


\section{Acknowledgments}

We would like to thank Ms Rosalva de Freitas Oliveira (Centro de Idiomas/UFVJM) who kindly revised the English language version of the manuscript.

\section{Disclosure}

The authors report no conflicts of interest in this work.

\section{References}

1. Belo VS, Oliveira RB, Fernandes PC, et al. Factors associated with intestinal parasitosis in a population of children and adolescents. Rev Paul Pediatr. 2012;30(2):195-201.

2. Pedrazzani ES, Mello DA, Pripas S, et al. Helmintoses intestinais. II- Prevalência e correlação com renda, tamanho da família, anemia e estado nutricional. [Intestinal helminthiasis. II - Prevalence, correlation with income, family size, anemia and nutritional status. Rev Saúde Pública]. Rev Saúde Pública. 1988;22:384-389. Portuguese.

3. Saturnino AC, Nunes JF, Silva EM. A. Relação entre a ocorrência de parasitas intestinais e sintomatologia observada em crianças de uma comunidade carente de Cidade Nova, em Natal - Rio Grande do Norte, Brasil. [Relation observed between the occurrence of intestinal parasites and symptomatology in children from Cidade Nova community wanting in Natal city - Rio Grande do Norte State, Brazil]. Rev Bras Anal Clin. 2003;35:85-87. Portuguese.

4. Muniz-Junqueira MI, Queiroz EF. Relationship between protein-energy malnutrition, vitamin A, and parasitoses in children living in Brasília. Rev Soc Bras Med Trop. 2002;35(2):133-141.

5. Lima GM, Cotrin, GS. Enteroparasitoses: prevalência nos alunos da Escola Estadual Carneirinho - MG. [Enteric parasitics: prevalence in students of public school from Carneirinho, MG]. Rev Bras Anal Clin. 2004;4: 231-232. Portuguese.

6. Patz JA. A human disease indicator for the effects of recent global climate change. Proc Natl Acad Sci U SA. 2002;99(20):12506-12508.

7. Uchoa CM, Lobo AG, Bastos OM, et al. Parasitoses intestinais: prevalência em creches comunitárias da cidade de Niterói, Rio de Janeiro - Brasil. [Intestinal parasitism: prevalence in day-care centers of Niterói city, Rio de Janeiro - Brazil]. Rev Inst Adolfo Lutz. 2001;60:97-101. Portuguese.

8. Coelho LM, Oliveira SM, Milman MH, et al. Detecção de formas transmissíveis de enteroparasitas na água e nas hortaliças consumidas em comunidades escolares de Sorocaba, São Paulo, Brasil. [Detection enteroparasites transmissible forms in water and raw vegetables consumed in pre-schools from Sorocaba, São Paulo State, Brazil]. Rev Soc Bras Med Trop. 2001;34:379-482. Portuguese.

9. Freitas AA, Kwiatkowski A, Nunes SC, et al. Avaliação parasitológica de alfaces (Lactuca sativa) comercializadas em feiras livres e supermercados do município de Campo Mourão, Estado Paraná [Occurence of parasites in lettuce (Lactuca sativa) commercializaed in the street markets and supermarkets of Campo Mourão, state of Paraná, Brazil]. Acta Sci Biol Sci. 2004;26:381-384. Portuguese.

10. Cieffi PP, Waldman EA, Waldman CCS, et al. Aspectos epidemiológicos das enteroparasitoses no Estado de São Paulo, Brasil. [Epidemiological aspects of enteroparasitosis in the Estado de Sao Paulo, Brazil]. Rev Paul Med 1982; 99:34-36. Portuguese.

11. Levai VE, Amato Neto V, Campos R, et al. Pesquisa de ovos de helmintos e cisto de protozoários em dinheiro. [Research into the transmission of helminthic eggs and protozoan cysts on money]. Rev Saúde Pública. 1986;20:33-36. Portuguese.

12. Piccolo L, Gagliani LH. Estudo da prevalência de helmintos e protozoários em notas de dinheiro (papel moeda) em circulação na Baixada Santista. [Study of the prevalence of helminths and protozoa In money notes (paper money) in circulation in the Baixada Santista]. UNILUS. 2008;5:13-19. Portuguese.
13. Oliveira VC, Mello RP, Almeida JM. Dípteros muscóides como vetores mecânicos de ovos de helmintos em jardim zoológico, Brasil. Muscoid dipterans as helminth eggs mechanical vectors at the zoological garden, Brazil]. Rev Saúde Pública. 2002;36:614-620. Portuguese.

14. Thyssen PJ, Moretti TC, Ueta MT, et al. O papel de insetos (Blattodea, Diptera e Hymenoptera) como possíveis vetores mecânicos de helmintos em ambiente domiciliar e peridomiciliar. [The role of insects (Blattodea, Diptera, and Hymenoptera) as possible mechanical vectors of helminths in the domiciliary and peridomiciliary environment]. Cad Saúde Publica. 2004;20:1096-1102. Portuguese.

15. Pedroso RS, Siqueira RV. Pesquisa de cistos e protozoários, larvas e ovos de helmintos em chupetas. [A study on protozoan cysts, helminth eggs and larvae in pacifiers]. J Pediatr. 1997;73:21-25. Portuguese.

16. Coelho LM, Sobrinho TA, Oliveira SM, et al. Ovos e larvas de helmintos nos sanitários de pré-escolares municipais de Sorocaba, SP e suas frequências nas fezes das crianças. [Helminth eggs and larvs in the water closet of some city nursery schools (Infant Educational Center) from Sorocaba, SP, Brazil, and their frequency in children feces]. Rev Soc Bras Med Trop. 1999;32:647-652. Portuguese.

17. Silva AT, Massara CL, Murta FG, et al. Ovos de Enterobius vermicularis em salas de espera e banheiros de unidades básicas de saúde (UBS) do município de Nova Serrana-MG: contribuições para o controle. [Enterobius vermicularis eggs in basic health unit waiting rooms and toilets in the city of New-Serrana, MG, Brazil: contributions to control]. Rev Patol Trop. 2013;42:425-433. Portuguese.

18. Murta FL, Massara CL. Presença de ovos de helmintos intestinais em ônibus de transporte público em Belo Horizonte - Minas Gerais, Brasil. [Presence of eggs from intestinal helminths in buses of the public transport system in Belo Horizonte city, Minas Gerais State]. Rev Patol Trop. 2009;38:207-212.

19. Instituto Brasileiro de Geografia e Estatística. [Brazilian Institute of Geography and Statistics]. Available from: http://censo2010.ibge.gov. br/pt/censo-2010; 2010. Accessed February 14, 2017.

20. Graham CF. A device for the diagnosis of Enterobius infection. Am J Trop Med. 1941;s1-21(1):159-161.

21. Pereira EB, Rodrigues SL, Bahia-de-Oliveira GH, Coelho SV, Barata RA. Detection of intestinal parasites in the environments of a public school in the town of Diamantina, Minas Gerais State, Brazil. Rev Inst Med Trop São Paulo. 2016;58:51.

22. Ferreira DF. SISVAR: um programa para análises e ensino de estatística. [Sisvar: a program for analysis and teaching of statistics]. Rev Cient Symposium Lavras. 2008;6:36-41. Portuguese.

23. Moreno AC, Filho AF, Gomes Tdo A, et al. Etiology of childhood diarrhea in the northeast of Brazil: significant emergent diarrheal pathogens. Diagn Microbiol Infect Dis. 2010;66(1):50-57.

24. Gonçalves AL, Belizário TL, Pimentel JB, Penatti MP, Pedroso Rdos S. Prevalence of intestinal parasites in preschool children in the region of Uberlândia, State of Minas Gerais, Brazil. Rev Soc Bras Med Trop. 2011; 44(2):191-193.

25. Assis EM, Oliveira RC, Moreira LE, et al. Prevalência de parasitos intestinais na comunidade indígena Maxakali, Minas Gerais, Brasil. [Prevalence of intestinal parasites in the Maxakali indigenous community in Minas Gerais, Brazil]. Cad Saúde Pública. 2013;29:681-690. Portuguese.

26. Huggins DW, Medeiros LB, Oliveira ER. Himenolepíase: Atualização e prevalência no Hospital das Clínicas da Universidade Federal de Pernambuco. [Hymenolepiasis. A review and prevaience in the "Hospital das Clínicas da Universidade Federal de Pernambuco", Brazil]. Rev Patol Trop. 1993;22:57-70. Portuguese.

27. Borges CA, Costa-Cruz JM, Paula FM. Intestinal parasites inside public restrooms and buses from the city of Uberlândia, Minas Gerais, Brazil. Rev Inst Med Trop São Paulo. 2009;51(4):223-225.

28. da Silva JJ, Borges R, da Silveira AC, Pereira Silva L, Mendes J. Enterobiasis and other intestinal parasitoses in children attending educational institutions in Uberlândia, state of Minas Gerais, Brazil. Rev Patol Trop. 2003;32:87-94. 
Research and Reports in Tropical Medicine is an international, peerreviewed, open access journal publishing original research, case reports, editorials, reviews and commentaries on all areas of tropical medicine, including: Diseases and medicine in tropical regions; Entomology; Epidemiology; Health economics issues; Infectious disease; Laboratory science and new technology in tropical medicine; Parasitology; Public health medicine/health care policy in tropical regions; and Microbiology. The manuscript management system is completely online and includes a very quick and fair peer-review system. Visit http://www.dovepress. com/testimonials.php to read real quotes from published authors.

Submit your manuscript here: https://www.dovepress.com/research-and-reports-in-tropical-medicine-journal 